\title{
ON THE RELATIONSHIPS OF THE RHETORICAL, MODAL, LOGICAL, AND SYNTACTIC PLANES IN ESTONIAN PROVERBS
}

\section{Part 3}

\section{Arvo Krikmann}

\section{A CLOSE LOOK AT A FORMULA PATTERN}

We have selected a Who..., (that)...-model as the formula pattern to have a closer look at, and to sum up the report, we will make an attempt to study the behaviour of the formula in relations with other formulas and other structural aspects of proverbs.

\section{A. Relations with other implicative formulas}

As mentioned above, the typology of formulas outlined in the previous part of the article was merely a typology of the title texts of types in the publication Eesti vanasõnad (further: EV). In fact, every proverb type having a bigger number of records expresses a vivid internal variability, which is synonymy by nature and concerns besides the lexical form the sc. formula elements and the syntactic-modal form of sentences in general. At the moment we can estimate quantitatively the structural variability of Estonian proverbs only by the amount of the 'encounterings' or 'intersections' of proverbial units with formulas (or other features of form), not taking into account the record numbers behind each intersection.

At present it is not possible to assess the density of connection between the syntactic types of formula or other structural features in the corpus of Estonian proverbs as a whole either because the total potent and co-appearances of most formulas and other form features are yet unknown.

Let us make a simplified summary of proverbs which include texts with Who..., (that)... -formula (only or mostly or among others or 
as an exception), and have a glance at the co-appearance of other syntactic or modal stereotypes in these proverbs. The total number of such proverbs in EV-publication turned out to be 924 (let me remind you that according to the typification made on the basis of title texts the number of Who..., (that)...-formula proverbs, incl. all parallelist, imperative and other modifications, was only 590).

Nearly half of the group is made up of types where the Who..., (that)... -formula is altered by others; on the other hand, 347 of the 469 (i.e. ca. $3 / 4$ ) are the types represented by one record only.

Here are some of the most productive and steady representatives of Who..., (that)...-formula in Estonian proverbs:

Kes kopikat ei korja, see rublat ei saa (He who doesn't collect kopecks will not have a ruble) - EV 4360; ca. 210 records;

Kes kahju kardab, see õnne ei leia (He who fears loss, finds no happiness) - EV 2936; ca. 195 records;

Kes kõik nõmmed kõntsib, see kõik marjad maitseb (He who wanders all the moors, will taste all the berries) - EV 7631; ca. 80 records;

Kes ei täna pisku eest, see ei täna palju eest (He who doesn't thank for the little will not thank for a lot) - EV 12406; ca. 60 records.

Who..., (that)... -formula prevails strongly also in proverbs

Kes kannatab, see kaua elab (He who suffers [or: is patient] will live a long life) - EV 3174; ca. 200 records;

Kes valetab, see varastab (He who lies also steals [= Show me a liar and I'll show you a thief]) - EV 13278; ca. 110 records;

Kes ees, see mees (literally: He who comes first, is the man [=First come, first served]) - EV 507; ca. 95 records.

The Who..., (that)... -formula appeared to have the following number of variations with other implicative formulas:

1) elliptic formulas

2) If / When..., (then)...-formulas

3) formulas with initial Whose...

4) What..., (that)...-formulas

5) The more... -er, the -er...-formulas
94 cases;

89 cases;

17 cases;

10 cases;

8 cases; 
6) As..., so...-formulas

6 cases;

changes with other formulas are very small in number indeed.

According to this statistics the Who..., (that)... -formula seems to have quite a strong identity. Its basic synonyms are the most universal 'unmarked' representatives of symmetrical implicative structures - the elliptic structures and If / When..., (then)... -structures.

The general picture of variations in Estonian proverbs refers to the fact that the synonymy between the If / When..., then... -formula and the implicative ellipsis is extremely strong: e.g. there are 148 proverbs among our Who..., (that)... ones which also include the If / When..., (then)...-formula and/or the implicative ellipsis; both of them are present in 35 proverbs.

Furthermore, at least in Estonian proverbial language, but possibly even on a more general level occurs quite a spontaneous natural correlation between the implicative types of formula and the person of verb (in sentences lacking the substantive which mark the agent): the stereotypical cases are (He) who does $\sim$ is $\sim$ wants $\sim \ldots$ and (If / When you) do are $\sim$ want $\sim$.. forms. The statistics on archive texts support the fact:

\begin{tabular}{|l|r|r|}
\hline & 3rd person & 2nd person \\
\hline Who...,(that)... -formula & 1656 & 0 \\
\hline If / When..., (then)... -formula & 80 & 767 \\
\hline Implicative ellipsis & 90 & 609 \\
\hline
\end{tabular}

The representatives of Who..., (that)... -formula in the current study are the sentences with component Who (the consequent may also include pronouns in other cases, e.g. seda, sel, selle, etc.); the representatives of If / When..., then... -formula are the sentences where either of the formula's components occurs (i.e. is not ellipted); ellipses are the implicative texts where both formula elements are lacking (a verb might still occur). We have taken into account the purely indicative sentences as well as those which contain sincere, ironical or indecisive imperatives. e.g.: 
Kes aitab iseennast, seda aitab ka Jumal (Who helps himself will be helped by God);

Hoiad ise, siis hoiab Jumal ka (If you help yourself, the God will also);

Hoia ise, siis hoiab ka Jumal (Help yourself and the God will also);

also,

Kes huntidega elab, hakkab ulguma (He who lives among wolves will start howling);

Oled huntide hulgas, pead huntidega ulguma ([If you] live among wolves you must howl as wolves);

Kui oled huntide hulgas, siis ulu huntidega koos (If you are among wolves, then howl with wolves);

also,

Kes pätsi läheb otsima, see kautab kannika (Who goes to find a loaf will lose a cantle);

Pü̈̈ad pätsi, kaotad kannika ([If you] catch a loaf, [you will] lose a cantle);

Mine pätsi taga ajama, kauta kanikas ka ära (Go running after a loaf, and you will lose a cantle);

Ära mine pätsi taga otsima, kaotad viimaks kanikagi ära (Don't go after a loaf, or you will finally lose a cantle), etc.

My folkloristic intuition suggests that the proverbs of South-Estonia might favor the direct address 'sina' (you)-form as well as the totally elliptic way of saying, in any indicative or imperative sentence. Furthermore, my intuition suggests that these very features the frequent use of 2 nd person singular and elliptic style - are characteristic to Russian proverbs. The latter suggestion lacks evidence to prove it, the first one, however, does not. The results of this test are shown on the four following cartograms (see maps 1-4).

The density of distribution of each phenomenon was assessed by first finding the relative frequency of texts expressing this phenomenon (the percentage of the total number of texts in our survey) in each parish, then the numerical data of neighboring parishes were smoothed. Certainly, the current small test study pro- 


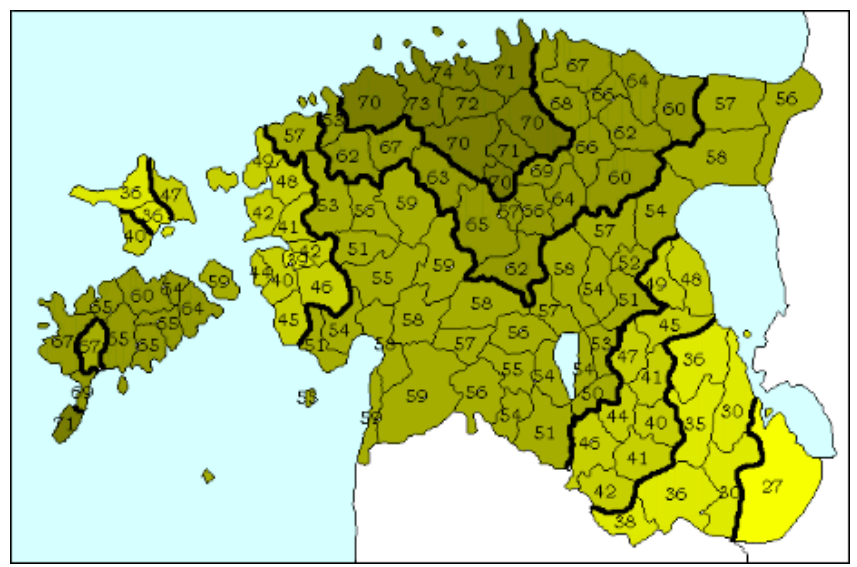

Map 1. The distribution of $(\mathrm{He})$ who..., (that)... -formula (the verb in $3 r d$ person singular).

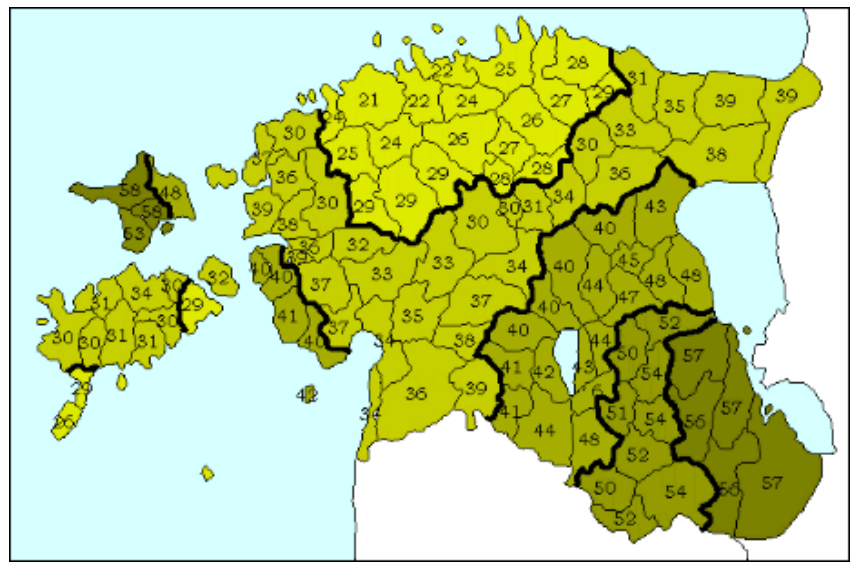

Map 2. The distribution of the 2 nd person singular in the elliptical implicative structures with If / When..., (then)... -formula. 


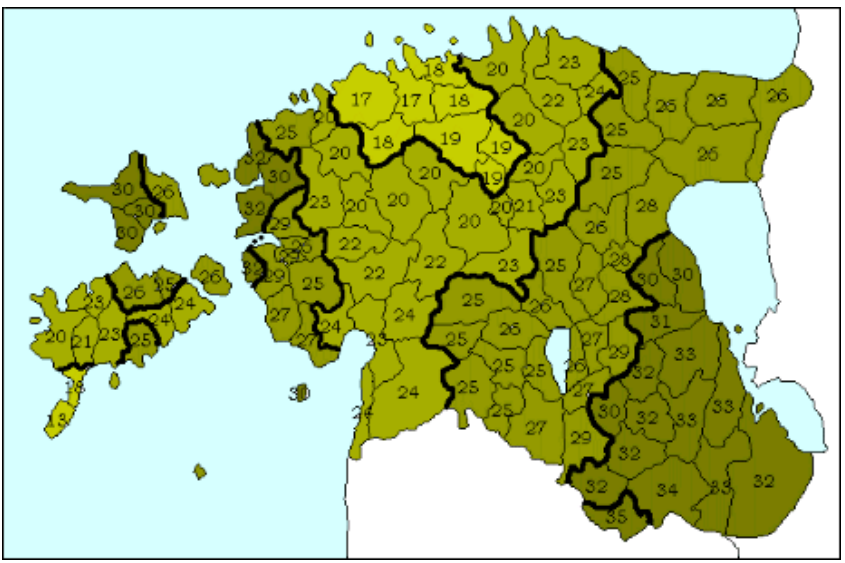

Map 3. The distribution of If / When..., (then)... -formula (the verb in 2 nd or $3 r d$ person singular).

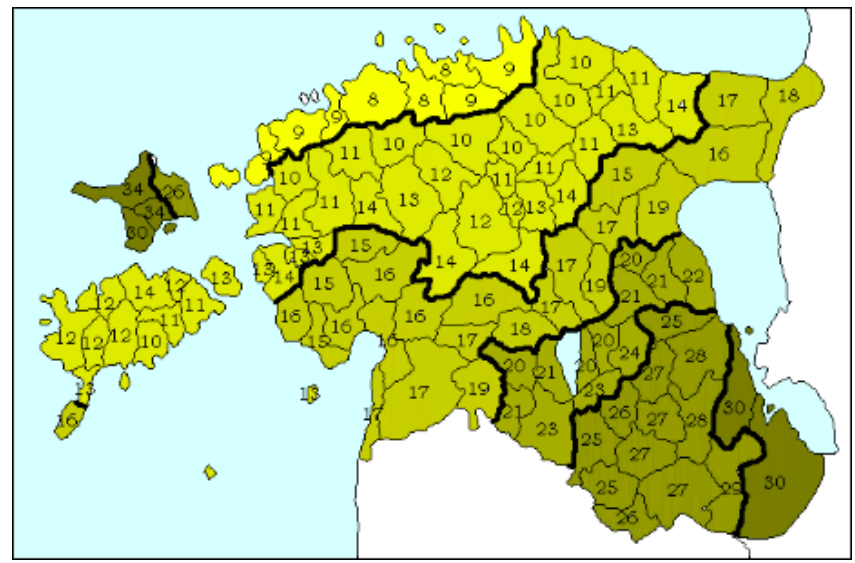

Map 4. The distribution of elliptical implicative structures (the verb in 2 nd person singular). 
vides no complete overview of the frequency relations of you-and he-modes in proverbs of different regions of Estonia, nevertheless, it proves that among the synonyms of Who..., (that)... -formula in Southern Estonia, and even more so in the south-eastern Estonia prevail the direct references in 2 nd person singular (map 2) and If / When..., then... -structures (map 3), and most plainly the elliptical implicative structures (map 4). The high rates in Hiiumaa on maps 2-4 are regretfully not reflecting the reality but noises (i.e. they result from the small total of the subject and the lateness of records).

\section{B. Parallelist forms}

In our study there is a total number of 107 proverbs with full parallelist texts, incl. the alteration of the implicative simple form with the parallelist-implicative form in 59 cases, the alteration of the implicative structure with the parallelist compound of two or more simple sentences in 24 cases, etc.

The parallelist forms are remarkable in a way that they can substantially and in different ways change the logical and the trope structure of a sentence.

The parallelist $(\mathrm{He})$ who..., (that)... -proverbs reveal quite distinct relations of synonymy (analogy) versus antonymy (opposition) between the parallelled components.

The synonymous parallelism in Who..., (that)... -proverbs is expressed in the following examples:

Kis hiljaks jääb, sii ilma jääb, kis kaua magab, see kahjatseb (He who comes late, gets nothing, he who sleeps long, will regret) - EV 1263;

Kes hoiab, ei ohka, kes kardab, ei kahjatse (Who takes care will not sigh, who fears will have no regrets) - EV 1416;

Kes kaarnat kasvatab, see silmad kautab, kes nõgest silitab, see käed kõrvetab (Who raises a raven will lose his eyes, who strokes a nestle will burn his hands) - EV $2832+7621$;

Kes kannatab, see kaua elab, kes järele annab, see järjel istub (He who suffers [or: is patient] will have a long life, he who yields will be well off [literally: sit on the throne]) - EV $3174+$ 2759 ; 
Kes koer, saab kolki, kes peni, saab pessa (Who is a dog will be drubbed, who is a cur will be caned) - EV 4197;

Kes konsiks [= konksuks] loodud, on nooreld kõver, ja kes okkaks loodud, on nooreld terav (Who is cut out for a hook will be twisted since his youth and who is cut out for a thorn will be sharp since his youth) - EV $4301+7792$.

The antonymous mode of parallelism is best expressed in cases where it is marked by the affirmative or negative form of a verb or adjective, by a pair of words, with one component denoting the 'contradictory' negation of another, or by antonyms marking various measures and qualities (big/small, many/few, good/bad etc.):

Kes see annab, see on saks, kes ei anna, see on sant (Who gives is a gent, who does not is a beggar) - EV 311;

Kes ei ike ehten, tuu ikk ellen, kes ikk ehten, tuu ei ike ellen (Who does not cry in wedding-clothes will cry in married life, who cries in wedding clothes will never in married life) - EV 2284; Kes külvab, see lõikab, kes ei külva, see ei lõika (Who sows will reap, who does not sow will not reap) - EV 5142;

Kes tööd teeb, see leiba sööb, kes laiskleb, see nälgib - (Who does his work will eat bread, who idles will starve) - EV 12466.

'If yes, then yes and if no, then no' -type of parallelisms contain a paremiological hyper-problem in a very clear manner: are all proverbs necessarily implications or are some of them still equivalences? For example, if we take a sentence: Kes teeb, see saab, kes ei tee, see ei saa (Who does will get, who does not will not get), then its only possible logical pattern should be

$$
\forall \boldsymbol{x}((\boldsymbol{P x} \rightarrow \boldsymbol{Q x}) \&(\overline{\boldsymbol{P}} \boldsymbol{x} \rightarrow \bar{Q} \boldsymbol{x}))
$$

which is firmly reduced to logical equivalence

$$
\forall \boldsymbol{x}(\boldsymbol{P x} \equiv Q \boldsymbol{Q}) \cdot
$$

If the proverb provides only the first part of this double structure, it is difficult to guess (even too strange to pose a question) whether it is presumed that those who will not do might somehow get, or they will not get for certain. The common sense would consider the presumption that they will not, more logical (cf. also Krikmann, 1987: 139-140). 
Contradiction can be expressed by more figurative means as well:

Kes härg sö̈b, see härg veab, kes sä̈äsk sööb, see sääsk veab (Who eats [like] an ox will 'drive' [i.e. work] like an ox, who eats [like] a gnat will 'drive' [i.e. work] like a gnat) - EV 1844;

Kes härra siin, sie härra sial, kie tüömies siin, sie tüömies põrgus (Who is a gent here will be a gent there, who is a worker here will be a worker in hell) - EV 1877;

Kes lusigaga alustab, see kulbiga lobetab, kes kulbiga alustab, see lusigaga lobetab (Who starts with a spoon will finish with a ladle, who starts with a ladle will finish with a spoon) - EV 4523 ;

Kis reede õhtu peseb, see peseb piimaga, kis laupäe õhtu peseb, see peseb verega (Who washes on a Friday night will wash with milk, who washes on a Saturday night will wash with blood) EV 5599.

As it turned out in the observation of the 7th trope type, parallelism is by no means indifferent towards the trope structure of proverbs. For parallelism to seem as opposing, its components must belong to one and the same "world", or semantic field. The number of possibilities is bigger in case of analogy parallelism, but our Who..., (that)... -group attached to a human being in both of its parallelled parts provides no adequate idea of this multiplicity. True enough, we might find here journeys through two different metaphoric regions (someone raises a raven and someone strokes a nettle; someone is a crooked hook and someone is a sharp thorn), but usually everything is reduced to pure lexical synonymy within the same semantic region. Naturally, we find no occurrence of trope type 7.1 here and type 7.3 could be found in a very few cases - e.g. EV 9637: Ega see pole rikas, kel palju on, vaid see on rikas, kes omaga rahul on (Not he is rich who has much, but he is rich who's contented with what he has) is based on the figurative polysemy of the word rikas (rich). But it is no coincidence that the synonymous parallelist compound is most often formed by the linking of two different proverbs.

In Who..., (that)... -group we can also find examples on multipartite parallelistic chains. Even bipartite parallelisms with a recurrent member in the consequent of the first part and in the anteced- 
ent of the second part can be conceived as a special kind of chain structure, e.g.:

Kes ei viitsi tööd teha, see peab kerjama, kes ei viitsi kerjata, see peab surema (Who does not care to work must beg, who does not care to beg must die) - EV 12465.

The chain might also be an analogy parallelism which is extended into three or more parts, for instance:

Kes palub, see saab, kes otsib, see leiab, kes koputab, sellele tehakse lahti (Who asks will be given, who seeks will find, who knocks at a door will be opened to $)$ EV $8377+5185+4380$.

Most often, the chain consists of three parts and is construed on the same principle as the folkloric tripartite in general, incl. in folk tales: in the 1st part the topical motive is established, in the 2nd part we will find the synonymous repetition, and in the 3rd part the turn (a point, a strong hyperbole, a transition to the abruptly different semantic domain or other elements contrasting the previous); so, the chain forms a climax:

Kes mehe riiet naerab, see naerab rätsepat; kes mehe nägu naerab, naerab Jumalat; kes mehe tegusid naerab, naerab meest ennast (Who laughs at man's clothes laughs at the tailor, who laughs at the man's face laughs at God, who laughs at man's deeds laughs at man himself) - EV 7163;

Annad põllule seitse kõrda, annab põld sada kõrda; annad põllule ühä kõrra, annab põld sulle seitse kõrda; narrid põldu ühä kõrra, narrib põld sinu seitse kõrda (If you give [i.e. dung] the field seven times the field will give a hundred, if you give the field once the field will give you seven times, if you taunt the field once it will taunt you seven times) - EV 9137.

In some cases which concern children's folklore and which proverbial nature is somewhat problematic, the play at parallelism takes place solely due to the fun of continuation (Lust zu erweitern) (see Krohn, 1926: 66ff.) and is orientated to the sounds, the comic and the absurd. 
A good example could be the proverb Kes ees, see mees (Who comes first will be the man) - EV 507, continuing with: ...kes keskel, see keiser kera kena oinas; kes taga, see taarinaga tataari naba $\sim$ tatikas $\sim$ talle saba (...who comes second will be a czar $\sim$ circle $\sim$ cute ram; who comes last will be kvass vat's peg Tatar's navel brat lamb's scut).

\section{The modal structure of a sentence}

As I already mentioned, it is hard to imagine what purpose could be served with a proverb which provides no evaluation at all. But evaluations could be included in proverbs in several ways. Let us observe some more productive patterns on the example of Who..., (that)... -proverbs.

\section{C1. "Bonuses" and "penalties"}

In the antecedent, the who-person performs deeds which are seen as either willful or optional; in the consequent there follows something which is either good or bad for the who-person.

\section{C1a1. "Bonus", a favorable result for the who-person - ca. 85 proverbs}

It is somewhat difficult to point out the kinds of 'bonus' from the mixture of literal speech and metonymy, still, we could distinguish certain stereotypes.

Most often it refers to food, gain, haul, wealth, or the avoidance of hunger, want, etc., respectively:

Kes kibedat kannatab, see magusat maitseb (He who suffers the bitter will taste the sweet) - EV 3684;

Kes higiga teeb, see himuga sööb (Who works in sweat will eat with appetite) - EV 12485;

Kes kass roidab, sii oma poja toidab (The cat who snoops around will feed his kitten) - EV 3393;

Kes tööd teeb, see nälga ei näe (Who works hard will feel no hunger) - EV 12460;

Kes üksi rohmib, üksi pohmib (Who works hard alone will gobble alone) - EV 15089. 
We can also find obscure references to the gain of something good, managing, success, position, survival:

Kes otsib, see leiab (He who seeks shall find) - EV 8147;

Kes tahab, see saab (Who wants will get) - EV 11480;

Kis pusib, sie suab (Who bungles will get) - EV 9066;

Kes pü̈̈ab, see jõuab (He who takes pains will get things done) EV 9400;

Kes sõuab, see jõuab (He who rows goes far) - EV 11180).

The promises might also concern physical strength, knowledge, wisdom:

Kes palju sööb, see palju teeb (Who eats a lot will do a lot) - EV 8335;

Kes süöb, sie jaksab (Who eats will be strong) - EV 11241;

Kiä här'ä süü, tuu mäe tege (Who eats a lot [literally: an ox] will make a mountain) - EV 1847);

Kes palju küsib, saab targemaks (Who asks a lot will get wiser) EV 5187;

the blessing of God:

Kes vaesele annab, sellele tasub Jumal saja võrra (Who gives to the poor will be rewarded by God for a hundred) - EV 13027; Kes tööd teeb ja vaeva armastab, seda aitab Jumal (Who toils and moils will be helped by God) - EV 12457;

Kesse kassi kallistab, selle õue onnistab (Who cuddles a cat, his farmyard will be blessed) - EV 3394;

Kes aitab iseennast, seda aitab ka Jumal (Who helps himself will be helped by God) - EV 1424;

the love and gratitude of fellow men:

Kes on hea, see kiitust saab (Who is good will be rewarded) - EV 1094;

the avoidance of negative emotions:

Kes kannatab, see ei kahetse (Who suffers will have no regrets) EV 3173. 


\section{C1a2. "Penalty", an unfavorable outcome for the who-per- son - ca. 230 types}

This pattern is probably the most productive one among the proverbs. The stereotypes are more or less the same as was the case with positive results.

The who-person is foretold e.g. physical inconvenience, trouble, danger, pain, injury or illness:

Kes viiga ümbre käü, tuu õks hämmest ka saa (Who handles water is bound to get wet) - EV 13957;

Kes kõrgest kukub, saab kõva hoobi (Who falls from height will suffer a hard blow) - EV 4859;

Kes valega haukap, sii valuga neelätäp (Who bites with a lie will swallow with pain) - EV 13240.

Most often (ca. 60 cases) the boding involves hunger, material damage, poverty, bad harvest, or the bad quality of something:

Kes kõik pühad peab, see kõik näljad näeb (Who celebrates all holidays will face all hungers) - EV 9361;

Kes liha otsib, see kondi leiab (Who looks for meat will find a bone) - EV 5802;

Kes tööd ei tee, see sü̈̈a ei saa (Who does not work will not get food) - EV 12453;

Kes kopikat ei korja, see rublat ei saa (Who doesn't collect kopecks will not get a ruble) - EV 4360;

Kes püvve lätt pü̈̈dma, kautas kana (Who goes to catch a partridge will lose a hen) - EV 9396;

Kes hiljaks jääb, see ilma jääb (Who is late will be left without) - EV 1263.

As with the promised goods, 'penalties' might take the form of a vaguely specified misfortune, failure, loss or damage:

Kes kardab, see kaotab (Who fears will lose) - EV 3271;

Kes ühte ei taha, sii kahte ei saa (Who doesn't want one will not get two) - EV 14881;

Kes tuult külvab, see tormi lõikab (Who sows a wind will reap a storm) - EV 12222; 
Kes algab hästi, lõpetab halvasti (Who starts well will finish badly) - EV 243;

Kes paljo kõneleb, teeb hendale vaeva (Who talks a lot will be in trouble) - EV 4835.

An unfavorable result might also appear in lack of knowledge, failure in accomplishing purposes, degradation in ethic or some other standards, etc.:

Kes vette ei hüppa, see ujuma ei õpi (Who does not jump into water will not learn to swim) - EV 13956;

Kes hirmuta kasvab, see auta elab (Who grows up without fear will live without honour) - EV 1296;

Kes sea seltsin eläb, nakkab ka viimätä sitta sü̈̈mä (Who lives together with a pig will end up eating shit) - EV 10339.

The who-person might also be subject to sin, perdition, the anger and punishment of God, he might fall prey to devil:

Kes külili sööb, teeb kümme pattu, kes selili sööb, teeb seitse pattu (Who eats lying on his side will commit ten sins, who eats lying on his back will commit seven sins) - EV 10268;

Kes kurja külvab, see hukatust lõikab (Who sows evil shall reap perdition) - EV 4596;

Kes laubaõsta vistleb, seda Jumal nustleb (Who whisks himself on a Saturday will be punished by God) - EV 5598;

Kes kuratille annab sõrmeotsa, viimaks pärib iho ja hinge (Who gives the devil the tip of his finger will end up giving him his body and soul) - EV 4588.

A penalty might also be the violence of fellow men and society (beating, force, prosecution), cheating, "schooling in life", laughter and criticism, shame, distrust, hostility:

Kes koerust teeb, see kolki saab (Who is up to mischief will get beaten) - EV 4197;

Kes kurja teind, see kurja vastab (Who has done evil will answer for evil) - EV 4598;

Kes koer om, see koera palga saab (Who is a dog [i.e. acts mischievously] will get dog's pay) - EV 4068; 
Kis sandikeppi ja vangitorni naerab, see saab isi ka vangi (Who laughs at beggar's staff and roundhouse will be put to prison himself) - EV 13647;

Kes pehme om, perse ala pandas (Who is [too] soft will be sat on) - EV 8519;

Kes pea usup, saap pea petetus (Who believes [too] soon will be deceived soon as well) - EV 12949;

Kes vanemate sõna ei võta, küll seda ilm õpetab (Who does not obey the parents' word will be taught by the world) - EV 2206; Kes kord on valetanud, seda teist kord enam ei usta (Who has lied once will not be believed the second time) - EV 13276;

Kes häbi otsib, häbi leiab (Who seeks shame will find shame) EV 1718.

Negative emotions:

Kes paljo lainas, see paljo leinas (Who borrows [or: lends] a lot, will regret [literally: mourn] a lot) - EV 8314;

Kes hooletu, see onnetu (Who is careless will be unhappy) - EV 1494;

Kes keeldu ei kuule, peab kahetsema (Who does not obey forbidding will regret afterwards) - EV 3541;

Kes palju lubab, see palju kahetseb (Who promises a lot will regret a lot) - EV 8320;

Kes varra naard, see hilda ikk (Who laughs early will cry later) EV 13670.

\section{C1b. The figure of speech allows the interpretation of both "bonus" and "penalty" - ca. 10 types:}

Kes kõik nõmmed kõntsib, see kõik marjad maitseb (Who wanders all the moors will taste all the berries) - EV 7631;

Ken kaik katsub, sie monda nägeb (Who touches [i.e. tries out] all will see many a thing) - EV 3459;

Kes midake ots, tood tole saa (Who seeks something will get that) - EV 8146;

Kes väikselt alustab, lõpetab suureste (Who starts with small will end up with big) - EV 14452;

Kes mida külvab, see seda lõikab (Who sows what shall reap that) - EV 5150. 


\section{C1c. Parallelist sayings, where the consequent of one com- ponent has the meaning of "bonus", whereas the consequent of the other component has the meaning of "penalty"}

This small group reveals the connection between parallelism and the axiological structure of a proverb. Part of the examples of this group are already quoted in paragraphs about the antonymous and chain parallelism; we will add some more to these:

Kes niidab lamba pea, elab paar päeva, kes saba, see sada aastat (Who shears the sheep's head will live a couple of days, who shears its tail will live a hundred years) - EV 7431;

Kes leivaga kerjama läheb, tuleb tükiga tagasi, aga kes tükiga läheb, tuleb leivaga tagasi (Who goes out begging with a bread will come back with a piece, who goes out with a piece will come back with a bread) - EV 5662 .

\section{C2. The "quasi-bonuses" and "quasi-penalties"}

The "reality" of bonuses or penalties was not one and the same in the previous series 1a-1c either: hunger or pain is obviously somewhat more perceptible than, for instance, the want of spiritual welfare; still, the consequent of the implication has so far allowed a serious interpretation in the ontologic sense, it was possible to establish a causative bridge between the antecedent and the consequent. We can still find proverbs where the establishment of such bridges and the serious interpretation fails, i.e. we are concerned with the, say, "quasi-penalties" or, exceptionally, with "quasi-bonuses". This is a genetically heterogeneous, in many ways hybrid and an interesting subject - the fusion of the ontological and the evaluative-normative, often the symbiosis of mythological and rhetorical, where the original superstitious function has been reduced to the rhetoric or has never even existed, and a superstition (or a customary regulation) is being imitated and simulated. Thus folk pedagogy arms itself with the mimicry borrowed from folk religion and customs. Their second function is to make jokes, i.e. they might be regarded as a kind of parodies on proverb and religion (see also Krikmann, 1985: 480). As tropes, the "quasi"-units are usually hyperboles. 
C2a. The "quasi-bonuses" might be found in single examples where the feeling of invertibility results from a rough dissonance between the antecedent and the consequent in the plane of commonplace / sacred or significant / insignificant:

Kes lese auku harib, see taevariiki pärib (Who takes care of a widow's 'hole' will inherit the heavenly kingdom) - EV 5759;

Kes sitika tee peal õieti pöörab, saab ühe pulga ülemale (Who sets a bug on its feet on the path will step up the staircase [to heaven]) - EV 10524;

also, a well-known alliterative set phrase: Kes kannatab, see kaua elab (Who suffers [or: is patient] will live long) - EV 3174.

C2b. There are more "quasi-penalties" - ca. 30 in our material. The distinct motivation of these often grotesque and absurd figures is hard to determine. By large, we could distinguish:

the units, where a power of unknown origin seems to operate, spreading grotesque failures and diseases, post-mortal horrors, etc:

Kes naeru kardab, see peeru sureb (Who fears laughing will die of fart) - EV 7136;

Kes kusemata situb, see n-mata sureb (Who shits without urinating will die without f-ing) - EV 4688;

Kes naar, saa nagla (Who laughs will get a furuncle) - EV 7156; Kes ähvardades ära sureb, see peeretades maha maetakse (Who dies threatening will be buried with farting) - EV 14776;

Kes lihahimus eläb, sii rasvanälgä surep (Who lives in lust [for flesh] will die in hunger for fat) - EV 5822;

Kes isa ehk ema lööb, selle käsi kasvab hauast välja (Who strikes his father or mother his hand will grow out of the grave) - EV 2207 ;

the units, which simulate sanctions following from customary law:

Kes vana asja meelde tuletab, sel silm peast välja (Who reminds [others] of an old thing will have his eye picked out) - EV 13329; Kes tangupudruga leiba sööb, see saadetakse Siberisse (Who eats bread with barley porridge will be sent to Siberia) - EV 11580; Kes mullust mälets ja toonast miili tulets, sel lõigats tõine kõrv äräde (Who reminds of the past and recall what has been will have his ear cut off) - EV 6882. 


\section{C3. "Signalling"}

In this group, the who-person is an object observed from outside. The antecedent part expresses his more distinct outward qualities that appear in a certain situation, the consequent provides predictions about his other, often hidden features which may compensate or annul what has been said in the first part, or the information given in the antecedent is spread on the other occasions (times, places), or it predicts the further course of the situation the whocharacter is in, etc.

\section{C3a. Signals of the good qualities of the who-person}

Diligence, mettle, ability occur most frequently here:

Kiä um susi suule, tuu um kahr tü̈̈le (Who eats [or: is agressive] like a wolf will work like a bear) - EV 10788;

Ken noorelt nobe, see virk vananagi (Who is quick in youth will be diligent in old age) - EV 7469;

Kes mees siin, see mees seal (Who is man here will be a man there) - EV 6507;

Kes ühest mees, see teisest mees (Who is a man for one thing will be a man for another) - EV 14879 .

Wisdom and broad-mindedness, kindness, keeping one's word and fidelity a.o. qualities are mentioned as well:

Kes tark, see võtab õpetust (Who is smart will learn) - EV 11603; Kes palju käind, see palju näind (Who has travelled a lot has seen a lot) - EV 8319;

Kes kassi hoit, tuu hoit ka hobõst (Who takes care of a cat will take care of a horse too) - EV 3390.

\section{C3b. Signals of the bad qualities of the who-character}

Proverbs consider socially evil or dangerous those who are, deciding by the outward features either

untrustworthy, liars or thieves:

Kes usutav ei ole väikesin asjun, see ei ole suurin eälgi (Who can not be trusted in small things can not be trusted in big things) EV 8879; 
Kes palju räägib, see palju valetab (Who talks a lot lies a lot) EV 8328;

Kes varastab, see valetab (Who steals that also lies) - EV 13776;

Kes valetab, see varastab (Who lies that also steals) - EV 13278;

evil, bad, naughty (as a dog):

Kes kodu karjub, see eemal haugub (Who shouts at home will bark away from home) - EV 3964;

Keä make, tuu tike (Who is oily is also cruel) - EV 6325;

Kes vihane üte pääle, see vihane tõise pääle (Who is angry with one is angry with the other) - EV 14030;

Kes koer elades, see koer surres (Who lives as a dog will die as a dog) - EV 4050;

Kes koer siin, see koer seal (Who is a dog here will be a dog there) - EV 4104;

dumb, ignorant:

Kiä noorõlt nuiatükk, tuu vanalt puupala (Who is a piece of stick in youth will be a block of wood in old age) - EV 7478;

Mis loll ôta, see loll hommiku (Who is stupid in the morning will be stupid in the evening) - EV 6015;

Kes loll sündides, see loll surres (Who is born stupid will die stupid) - EV 6000;

stingy:

Kea antust ei anna, see ei anna kah aidast (Who does not share what he is given will not share what he has in his barn) - EV 327 ;

Kes palju lubab, see vähe annab (Who promises much will give little) - EV 8321;

Kes om makõ, tuu sakõ (Who is oily is also stingy) - EV 6333;

lazy, sluggish:

Kes palju räägib, see vähe teeb (Who talks a lot will get little done) - EV 8330;

Kes elades laisk, see surres laisk (Whos's lazy when living will be lazy when dying) - EV 551; 
ungrateful, indifferent, makes difference between himself and others:

Kes ei täna pisku eest, see ei täna palju eest (Who does not thank for little will not thank for much) - EV 12406;

Kes teise silmas pinda näeb, see oma silmas palki ei näe (Who sees a mote in other's eye will not see a beam in his own eye) EV 11889;

Kes ise haavu ei ole kannatanud, naerab armide üle (Who has not suffered from wounds will laugh at scars) - EV 734.

\section{C3c. Good and bad signals in parallelist forms}

Kes lahke, sie laisk, kes tige, sie tegijä (Who is generous is lazy, who is angry is diligent [about wives]) - EV 5281;

Kes ei näe narmas, see ei näe silmas; kes näeb narmas, see näeb silmas (Who does not notice you in rags will not notice you in nice clothes, who notices you in rags will also motice you in nice clothes) - EV 7377.

\section{C3d. Axiologically indefinite signal}

This group contains proverbs with the philosophical content, which concern the relation between life and death, the unchangeable regularities of human psychology, fate and destiny, life's paradoxes, etc. which provide no active strategy for either who-person or others concerned. The most productive Estonians proverbs on this subject might be:

Kes sutt lätt pakku, lövväp kahro kate pojaga iist (Who flees from a wolf will find a bear with two sons instead) - EV 10801; Kes silmist, see meelest (Who is out of sight is out of mind) - EV 10450;

Kes kala mõrran, tuu taht vällä, kes vällän, tuu taht mõrda (The fish who is in the weir will want out, who is outside will want inside the weir) - EV 3059;

Kes korra põlend, kardab tuld (Who has been burned once is afraid of fire) - EV 9169;

Kes surmaks loodud on, seda ei aita arstirohud mitte (Who is doomed to death will not be cured by medicines either) - EV 10727; 
Kes ilma läind, see ilmas on (Who has gone out to the world will stay there) - EV 1987;

Kes supiga suu põletand, see puhub ka vee peale (Who has burnt himself with soup will blow on water as well) - EV 10698.

\section{C4. Sentences with purely evaluative consequent}

Here we cannot possibly apply any ontological meaning to the consequent, instead it obtains the purely evaluative quality (often via a nominal metaphor or comparison). This group also reveals that the normal or inverted order of the parts of implication (i.e. seemingly quite a formal matter) is a relevant determinant in the modal and trope structure of the sentence: while in sentences with ontologically interpretable consequent the normal word order was prevalent, purely axiologically interpretable consequent is more often placed at the beginning of the sentence.

Something analogous appears in sayings of preferential structure: there is a tendency to employ the symmetrical Rather $\sim$ Better $\sim$...than... -structure if both sides of the preference belong to one and the same semantic 'universe', and the asymmetrical simple sentence structure if the predicative part of the sentence constitutes a hyperbole (e.g. Parem kodu kooruke kui võõrsil võileib (Better a crumb at home than a bread and butter abroad) and Laps on enam kui laast (A child is more than a splinter)) - cf. also Krikmann, 1987: 141-142.

\section{C4a. Good evaluation to the who-person}

Some evaluations bear humorous or ironical connotations.

The evaluative words which occur most frequently are mees, tark, hea, rikas (man, wise, good, rich):

Tuu om mees, kes naise mõist võtta ja hobese osta (A man is who knows to marry a woman and buy a horse) - EV 6692;

Tark on see, kes tunneb, et ta alles rumal on (Wise is who admits he is still ignorant) - EV 11650;

See inimene on rikas, kes palju õppind (A man who has learned much is rich) - EV 9756. 
A few examples on other evaluative words and appraising comparisons:

Kes annab, sii om kuningas (Who shares is a king) - EV 311; Kes hädas meile abi teeb, see on õige sõber (Who helps us in trouble is a true friend) - EV 1778;

Kes on hea naise saanud, see on hea asja leidnud (Who has got a good wife has found a good thing) - EV 1093.

\section{C4b. Bad evaluation to the who-person}

The evaluative words denoting some indefinitely bad quality, miserableness: vaene, vilets, sitt (poor, miserable, poorly, shitty) etc.:

Vaene sant on see, kes ilma kotita kerjab (A poor beggar is the one who begs without a bag) - EV 13085;

Vilets, kes vene vesile jättäb (Who leaves the boat on water is miserable) - EV 14176;

Sitt miis om sii, kes kirveta kirikusse lääb (Who goes to church without his axe is a shitty man) - EV 14566.

The evaluative words denoting stupidity: narr, loll, rumal (fool, stupid, ignorant) etc.:

Narr on see, kes rohkem lubab, kui ta jõuab (He's a fool who promises more than he can make) - EV 7388;

Loll, kes kõhutäie ära teenib (He's a fool who earns [i.e. works too much for] a square meal) - EV 6009.

Evaluation by animal metaphors:

Lammas on, kes ennast niita laseb (It is a sheep who lets himself sheared) - EV 5430;

Kes koera saba kergitab, on ise koer (Who lifts a dog's tail is a dog himself) - EV 4047;

Pini, kiä pett, perse, kï̈ petta lask (Who cheats is a dog, who lets himself be cheated is an ass) - EV 8563.

References to erring against God:

Keä üle vanõmba lätt, tuu lätt üle Jumala (Who disobeys his parents, disobeys God) - EV 13634; 
Kes koeruse pärast kerjab, see varastab Jumalad (Who begs for the sake of mischief steals from the God) - EV 4196.

Evaluation is given by comparisons or extended metaphors:

Kes kolm kerda oo kolind, sie on justku tulekahjust läbi käünd (Who has moved for three times has as if lived through a fire [= Three removes are as good as a fire]) - EV 4279;

Kes naisel lüvvä lask, om niisama alato, kui olõsi tsiga purno (Who lets a woman slap him is as humiliated as if a pig has bitten) - EV 7199;

Kes ottab lese kolme lapsega, ottab neli varast majasse - (Who weds a widow with three children takes four thieves into his house) - EV 5758.

\section{C4c. Good and bad evaluation together}

Figural stereotypes are generally the same as in groups $4 \mathrm{a}$ and $4 \mathrm{~b}$. This compound structure once again illustrates the plurality of reasons evoking parallelism.

Let us have some examples of the occurrence of mees (man)-evaluation and the co-occurrence of words tark + loll (smart + stupid):

Koer, keda kutsutakse, aus mees astub ise (A dog who is called for, an honest man goes himself) - EV 4093;

Mees, kes saab, lits, kes laseb (A man who gets, a bitch who lets) EV 6573;

Tark, kes ajaga kaasa lääb, loll, kes sõrad vastu aab (Smart is the one who goes along with time, stupid is the one who bears his fangs) - EV 11636;

Tark, kes muigab, rumal, kes naerab (Smart who smiles, stupid who laughs) - EV 11637.

\section{C5. Forms which contain norms and imperatives}

The Who..., (that)... -group does not allow to demonstrate the modal synonymy involving imperatives too expressively, but it forms a logical final stage in our "consequent-orientated" typology. We found out that the consequent of Who..., (that)... -proverb might predict, for the who-character himself or his fellow men, axiologi- 
cally marked real or quasi-situations and events, as well as provide direct axiological assessments, which enable to derive more or less definite prescriptions from them.

Eventually, it might contain direct prescription (i.e. order or interdiction). In such a case the first part of the proverb might report either already existing or optative situation, to achieve / preserve / avoid / liquidate which the imperative is for. All in all there are approximately 60 items with normative or imperative consequents among our who-proverbs.

\section{C5.1. Should has to / can / must not -type indicative stand- ardization}

Let us bring some examples for every deontic predicate (in the examples we have tried to avoid sentences where peab means is forced to').

\section{Peab- (Should $\sim$ has to) -sentences and other obliging indicatives:}

Kes supi teeb, see supi sööb (He who cooks the soup must eat it up himself [i.e. who messes up will bear the consequences]) EV 11234;

Kes tahab teisi õpetada, see peab ise õppinud olema (Who wants to teach others has to be learned himself) - EV 14752;

Kes tapab, sii matab (Who kills has to bury) - EV 11589;

Kes algab, peab lõpetama (Who starts something has to finish it) - EV 244;

Kes võla võtab, see peab võla maksma (Who borrows has to pay back his debt) - EV 14316.

\section{Ei tohi / ei pea- (must not / need not) -sentences:}

Kes ei taha tööd teha, see ei pea ka sööma (Who does not want to work, need not to eat) - EV 12448;

Tüdruk, kes mehe pükste jalge vahele lappi ei oska panna, see ei tohi üleüldse mehele minna, sest mis mees niisuguse lolli naisega tegema hakkab (A girl who cannot patch man's trousers in between the legs, must not marry at all, because what use does a man have of such a stupid wife) - EV 12597. 
Võib / tohib- (can / is allowed) -sentences (they all happen to be humorous preconditions for marriage):

Kes ahjuluuda mõistab siduda, kotikangast kududa ja seasoolikaid pöörata, see on meheleminemiseks küps (Who can tie an oven brush, weave a sackcloth and turn over chitterlings is ready for marriage) - EV 177;

Kis mees söögivahes sada teevast käe otsas ära vahendab, see võib naese võtta (The man who can sharpen hundred stakes between two meals, can take a wife) - EV 6510.

\section{C5.2. gu- (should, let) -imperatives}

Here, we will not make an attempt to distinguish the 'sincere' imperatives from the gloating-ironical or warning-ironical ones, instead we will just bring some examples of sentences with second parts containing $g u$-imperative.

It is practically impossible to translate the gu-imperative into English, therefore the translation is provided by the meaning solely.

\section{Orders:}

Kes perse teisele laenab, sitku ise läbi küljeluude (Who loans his ass to someone else should shit through his ribs) - EV 8683; Kes oma sõbrast tahab vaenlast teha, see laenaku talle raha (Who wants to makes his friend his enemy should loan him some money) - EV 11056;

Kes on pandud orjama, see orjaku hea meelega (Who is made to slave should do it with pleasure) - EV 8109.

\section{Prohibitions:}

Kes kord "jaa" on öelnud, ärgu öelgu enam "ei" (Who has said 'yes' once already should not say 'no' any more) - EV 2293;

Kes hunti kardab, see metsa ärgu mingu (Who is afraid of wolf should not go into the woods) - EV 1655.

Obviously, the Who..., that... -structure almost automatically excludes direct imperatives from consequent clauses. Considering the general prevalence of negative (all the bad things, prohibitions) 
over positive in proverbs, the total of indicative and $\ddot{a r g} u$-prohibitions is surprisingly scarce as well. Apparently, this tendency is also somehow in accordance with the paremic "3rd person ideology".

Translated by Kait Realo

\section{References}

Eesti vanasõnad 1980-1988. Ed. by A. Krikmann \& I. Sarv. Comp. by A. Hussar, A. Krikmann, E. Normann, V. Pino, I. Sarv, R. Saukas. Vol. I-V: 2. Tallinn.

Krikmann, A. 1985. Vanasõnaparoodiatest. Keel ja Kirjandus, No. 8.

Krikmann, A. 1987. 1001 küsimust vanasõnade loogilise struktuuri kohta. Dialoogi mudelid ja eesti keel. TRÜ toimetised, No. 795. Tartu, pp. 120-150.

Krohn, K. 1926. Die folkloristische Arbeitsmethode. Oslo. 